\title{
Significance of determination of hemodynamic phenotypes in early diagnosis of cardiovascular disorders in children with diabetes mellitus
}

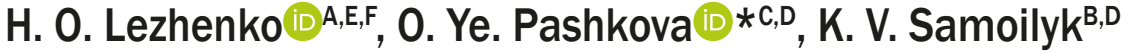

Zaporizhzhia State Medical University, Ukraine

A - research concept and design; B - collection and/or assembly of data; C - data analysis and interpretation; D - writing the article;

$\mathrm{E}$ - critical revision of the article; $\mathrm{F}$ - final approval of the article

Aim. To stratify hemodynamic phenotypes in children with diabetes mellitus and their frequency, depending on the duration of the disease.

Materials and methods. The study involved 72 children suffering from diabetes, aged 10 to 16 years who were divided into 3 groups. The first group -22 children with diabetes mellitus up to 1 year. The second group -24 patients with a disease duration of 1 to 5 years. The third group -26 children with the disease over 5 years. Control group -20 children, representative by age and sex.

All children underwent daily blood pressure monitoring (ABPM) with the ABPM-04 device (Meditech Ltd, Hungary). Diagnosis of latent hemodynamic disorders was performed by the method of quantitative analysis of the relationships of blood pressure parameters, which involved a linear regression of systolic blood pressure by pulse blood pressure. According to the results of regression, 6 hemodynamic phenotypes were determined, which characterized the individual features of the circulatory system: harmonic, myocardial-insufficient subtype of harmonic, borderline diastolic harmonic, borderline systolic harmonic, dysfunctional diastolic and dysfunctional systolic. According to ABPM results, the ambulatory arterial stiffness index (AASI) was calculated using a linear regression equation. The results were statistically processed using statistics software package Statistica 13.0 (StatSoft Inc., No. JPZ8041382130ARCN10-J).

Results. It was found that in the dynamics of diabetes the registration of the harmonic hemodynamic phenotype during the day decreased due to an increase in the proportion of patients with dysfunctional diastolic hemodynamic phenotype. At the same time, in children with diabetes, there was a significant increase in AASI from the first year of the disease with a progressive increase with its dynamics. The highest values of AASI were observed in dysfunctional hemodynamic phenotype.

Conclusions. In children with diabetes mellitus observed the formation of disharmonious hemodynamic phenotypes in the dynamics of the disease. In combination with increased vascular stiffness these changes realized in systemic circulatory disorders and the development of a diabetic angiopathy. Detected disorders, apparently, became the risk factors of hypertension. Determination of hemodynamic phenotype in children with diabetes mellitus can be used as screening method for preclinical diagnosis of latent disorders of the cardiovascular system, early treatment and prevention.

Значення встановлення гемодинамічних фенотипів у ранній діагностиці серцево-судинних порушень у дітей, які хворі на цукровий діабет

\section{Г. О. Аеженко, О. Є. Пашкова, К. В. Самойлик}

Мета роботи - здійснити стратифікацію гемодинамічних фенотипів у дітей, які хворі на цукровий діабет, та визначити їхню частоту залежно від тривалості перебігу захворювання.

Матеріали та методи. Обстежили 72 дітей, які хворі на цукровий діабет, віком від 10 до 16 років. Пацієнтів поділили на 3 групи: перша - 22 дитини з тривалістю цукрового діабету до 1 року, друга - 24 особи з тривалістю захворювання від 1 до 5 років, третя - 26 пацієнтів із перебігом захворювання понад 5 років. Контрольна група - 20 дітей, репрезентативних за віком і статтю.

Усім дітям виконали добове моніторування артеріального тиску (ДМАТ) на приладі ABPM-04 (Meditech Ltd, Угорщина). Діагностику латентних гемодинамічних порушень здійснили методом кількісного аналізу зв'язків параметрів артеріального тиску, що передбачав виконання лінійної регресії систолічного артеріального тиску (АТ) за пульсовим AT. За результатами регресії визначали 6 гемодинамічних фенотипів, які характеризували індивідуальні особливості функціонування системи кровообігу: гармонійний, міокардіально-недостатній підтип гармонійного, пограничний діастоло-гармонійний, пограничний систоло-гармонійний, дисфуннціональний діастолічний і дисфункціональний систолічний. За даними ДМАТ за допомогою лінійного регресійного рівняння розраховували амбулаторний артеріальний індекс жорсткості (Ambulatory Arterial Stiffnes Index - AASI). Статистично результати опрацювали за допомогою пакета статистичних програм Statistica 13.0 (StatSoft Inc., № JPZ8041382130ARCN10-J).

Результати. Встановили, що в динаміці цукрового діабету відбувається зменшення реєстрації гармонійного фенотипу гемодинаміки протягом доби внаслідок збільшення частки пацієнтів із дисфункціонально-діастолічним гемодинамічним фенотипом. Водночас у дітей, які хворі на цукровий діабет, виявили вірогідне підвищення AASI з першого року захворювання із прогресивним його збільшенням у динаміці. Найбільші значення AASI встановили при дисфуннкціональних гемодинамічних фенотипах.
Key words: diabetes mellitus, adolescent, hemodynamics, cardiovascular system.

Pathologia 2021; 18 (2), 167-173

*E-mail: elenapashkova0901@ gmail.com

Ключові слова: цукровий Аіабет, підмітки, гемодинаміка, серцево-судинна система.

Патологія. 2021.

T. 18, № 2(52). C. $167-173$ 
Висновки. У дітей, які хворі на цукровий діабет, у динаміці захворювання відбувається формування дисгармонічних гемодинамічних фенотипів, що разом зі зростанням жорсткості судин реалізується порушенням системного кровообігу, розвитком діабетичної ангіопатії та, вочевидь, є фактором ризику виникнення артеріальної гіпертензії. Визначення гемодинамічного фенотипу в дітей, які хворі на цукровий діабет, можна використовувати як скринінговий метод доклінічної діагностики прихованих порушень серцево-судинної системи та раннього призначення лікувально-профілактичних заходів.

Ключевые слова: сахарный диабет, ПОАРОстКи, гемодинамика, сердечнососудистая система.

Патология. 2021.

T. 18, № 2(52).

C. $167-173$

\section{Значение определения гемодинамических фенотипов в ранней диагностике сердечно-сосудистых нарушений у детей, больных сахарным диабетом}

\section{Г. А. Аеженко, Е. Е. Пашкова, Е. В. Самойлик}

Цель работы - провести стратификацию гемодинамических фенотипов у детей, больных сахарным диабетом, установить их частоту в зависимости от длительности течения заболевания.

Материалы и методы. Обследовали 72 ребенка, больных сахарным диабетом, в возрасте от 10 до 16 лет. Пациентов поделили на 3 группы: первая - 22 детей с продолжительностью сахарного диабета до 1 года, вторая - 24 больных с длительностью заболевания от 1 до 5 лет, третья - 26 пациентов с течением заболевания более 5 лет. Контрольная группа - 20 детей, репрезентативных по возрасту и полу.

Всем детям проведено суточное мониторирование артериального давления (СМАД) прибором АВРМ-04 (Meditech Ltd, Венгрия). Диагностика латентных гемодинамических нарушений выполнена методом количественного анализа связей параметров артериального давления, который предусматривал проведение линейной регрессии систолического артериального давления (АД) по пульсовому АД. По результатам регрессии определяли 6 гемодинамических фенотипов, характеризующих индивидуальные особенности функционирования системы кровообращения: гармоничный, миокардиально-недостаточный подтип гармоничного, пограничный диастоло-гармонический, пограничный систоло-гармонический, дисфункциональный диастолический и дисфункциональный систолический. По данным СМАД с помощью линейного регрессионного уравнения рассчитывали амбулаторный артериальный индекс жесткости (Ambulatory Arterial Stiffnes Index - AASI). Статистически результаты обработали с помощью пакета статистических программ Statistica 13.0 (StatSoft Inc. № JPZ8041382130ARCN10-J).

Результаты. Установлено, что в динамике сахарного диабета происходит уменьшение регистрации гармоничного фенотипа гемодинамики в течение суток за счёт увеличения доли пациентов с дисфункционально-диастолическим гемодинамическим фенотипом. В то же время у детей, больных сахарным диабетом, отмечено достоверное повышение AASI с первого года заболевания с прогрессивным его увеличением в динамике. Наибольшие значения AASI установлены при дисфункциональных гемодинамических фенотипах.

Выводы. У детей, больных сахарным диабетом, в динамике заболевания отмечено формирование дисгармоничных гемодинамических фенотипов, что в сочетании с ростом жесткости сосудов реализуется нарушением системного кровообращения, развитием диабетической ангиопатии и, очевидно, является фрактором риска возникновения артериальной гипертензии. Определение гемодинамического фенотипа у детей, больных сахарным диабетом, может быть использовано в качестве скринингового метода доклинической диагностики скрытых нарушений сердечно-сосудистой системы и раннего назначения лечебно-профилактических мероприятий.

Diabetes is one of the growing challenges of the $21^{\text {st }}$ century. It has a negative impact on human health, and its growing prevalence has a significant negative economic effect. The number of patients living with diabetes in the world has tripled in the last 20 years. The rate of spread of the disease exceeds all forecasts: in 2010, it was projected that in 2025 the incidence will be 438 million, but according to the International Diabetes Federation, there are now 463 million people in the world with diabetes. More than 1.1 million of them are young people under the age of 20 . The prevalence of diabetes among children in Ukraine is growing. Thus, in 2010 it was 0.981 per 1000 children, and in 2018 - already 1.2 [2].

One of the early and common complications of diabetes is damage to the cardiovascular system [10]. Diabetes appears as a separate and independent risk factor for fatal and nonfatal cardiovascular disorders [7]. In childhood, the formation of cardiovascular complications in insulin-dependent diabetes mellitus occurs simultaneously with the development of the disease [9]. Therefore, early diagnosis of cardiovascular messages at the stage before clinical changes is very important. At present, there are no clear objective signs of risk management of cardiovascular disorders in children with diabetes. Identification of latent messages of cardiovascular function in children with diabetes will allow to improve early diagnosis and optimize ways to correct established messages.

\section{Aim}

To stratify hemodynamic phenotypes in children with diabetes and the frequency with which they occur, depending on the duration of the disease.

\section{Materials and methods}

The study was conducted at the endocrinology department of the Municipal Institution "Zaporizhzhia Regional Clinical Children's Hospital" of the Zaporizhzhia Regional Council. To achieve this goal, 72 children with type I diabetes (36 boys and 36 girls) aged 10 to 16 years were examined. Depending on the duration of the disease, all sick children were divided into 3 groups. The first group included 22 
children with a duration of diabetes up to 1 year (mean age $12.9 \pm 0.4$ years). The second group consisted of 24 patients with disease duration from 1 year to 5 years (mean age $-13.8 \pm 0.4$ years). The third group included 26 children with diabetes for more than 5 years (mean age $14.3 \pm 0.4$ years). The control group consisted of 20 children representative by sex and age, who at the time of the survey had disorders of carbohydrate metabolism and intercurrent diseases. The groups were representative by age, sex, and body mass index.

All children under observation underwent a thorough clinical examination. Clinical examination of the patient included: medical history, clinical examination, laboratory and instrumental methods. Daily blood pressure monitoring with the ABPM-04 device (Meditech Ltd, Hungary) using the oscillometric method of blood pressure measurement was undertaken for all children. Patients under observation were diagnosed with latent hemodynamic disorders by quantitative analysis of blood pressure parameters [5], which involved a linear regression of systolic blood pressure by pulse blood pressure (by difference between systolic and diastolic pressure):

$$
\begin{aligned}
& \mathrm{SBP}=\mathrm{Q}+\alpha \times \mathrm{PP} \\
& \mathrm{DBP}=\mathrm{Q}+(\alpha-1) \times \mathrm{PP}
\end{aligned}
$$

where SBP - systolic blood pressure;

DBP - diastolic blood pressure;

$\mathrm{PP}$ - pulse pressure;

$Q$ is the regression coefficient, that characterizes the cross section (blood pressure in the area of the attenuating pulse wave at $P P=0$ ). This indicator reflects the level of metabolism between blood and tissues;

$\alpha$ is the angular regression coefficient ("pressor"), which reflects the proportional involvement of the heart and blood vessels in the process of blood flow;

( $\alpha-1)$ - angular regression coefficient ("depressor"), reflects the inverse direction in relation to the "pressor" coefficient a participation in blood flow (elasticity of resistive vessels and skeletal muscle function).

According to the results of regression, 6 hemodynamic phenotypes were determined, which characterized individual features of the circulatory system functioning: harmonic, myocardial-insufficient subtype of harmonic, borderline diastolic harmonic, borderline systolic harmonic, dysfunctional diastolic and dysfunctional systolic (Table 1) [5].

The ambulatory arterial stiffness index (AASI) was calculated according to the daily blood pressure monitoring (ABPM). AASI was calculated using a linear regression equation describing the relationship between systolic and diastolic blood pressure of the patient according to the results of ABPM and was determined by the tangent of the angle of the obtained regression line:

$$
\mathrm{DBP}=\beta_{1} \times \mathrm{SBP}+\beta_{2} ; \mathrm{AASI}=\left(1-\beta_{1}\right)[1],
$$

where $\beta_{1}$ is the slope of the linear regression of DBP to SBP;

$\beta_{2}$ is the regression coefficient.

The results were statistically processed using the

\begin{tabular}{|c|c|c|}
\hline $\begin{array}{l}\text { The value of the } \\
\text { coefficient } \alpha\end{array}$ & $\begin{array}{l}\text { The ratio of SBP, } \\
\text { DBP, } Q\end{array}$ & Hemodynamic phenotype \\
\hline $1<\alpha<2$ & $\mathrm{Q}<\mathrm{DBP}<\mathrm{SBP}$ & Dysfunctional diastolic \\
\hline$\alpha=1$ & $\mathrm{Q}=\mathrm{DBP}<\mathrm{SPB}$ & Borderline diastolic harmonic \\
\hline $0<\alpha<1$ & $\mathrm{DBP}<\mathrm{Q}<\mathrm{SBP}$ & Harmonic \\
\hline $0<\alpha<0.5$ & & Myocardial-insufficient subtype of harmonic \\
\hline$\alpha=0$ & $\mathrm{DBP}<\mathrm{Q}=\mathrm{SBP}$ & Borderline systolic harmonic \\
\hline$-1<\alpha<0$ & $\mathrm{DBP}<\mathrm{SBP}<\mathrm{Q}$ & Dysfunctional systolic \\
\hline
\end{tabular}
statistical software package Statistica 13.0 (StatSoft Inc.,
Table 1. Criteria for determining hemodynamic phenotypes

No. JPZ8041382130ARCN10-J) with the determination of the arithmetic mean $(M)$, standard deviation $(\sigma)$ and mean errors (m). The median and quartile Me [Q1; 2 2] were used for the uneven distribution of traits and the nonlinear dependence. The method of correlation analysis with calculation of Pearson's correlation coefficient is applied. Student's t-test and Fisher's angular transformation (criterion j) were used to assess the differences in the compared groups. In cases where the distribution law was statistically significantly different from normal, the nonparametric Mann-Whitney test (U) was calculated as a nonparametric analogue of the Student's test. Differences were considered significant at $P<0.05$.

All procedures conducted in the children's studies complied with the ethical standards of the Institutional and National Research Committee and the 1964 Declaration of Helsinki and its subsequent amendments or comparable ethical standards. Informed consent was obtained from all the individual participants included in the study and their guardians. Complete data established by children, their parents and the doctor, who confirm the results of this study, are not publicly available due to limitations obtained in the initial order.

\section{Results}

The analysis of parameters of hemodynamic phenotypes in children with diabetes mellitus showed that in the dynamics of diabetes mellitus there was an increased level of coefficients $\alpha$ and ( $\alpha-1)$ during the day (Table 2).

The detected changes became statistically significant in patients of group $3(P<0.05)$, in whom these coefficients were statistically significantly higher than both the control group and similar indicators of patients with disease duration up to 1 year $(P<0.05)$.

In the analysis of these coefficients, depending on the period of the day, attention was drawn to their increase at night in children with diabetes in the first year of the disease, which indicated an increase in the role of systolic component in blood circulation and reduced diastolic role. The most significant changes were registered in children of group 3 , in which against the background of a 2.5 -fold increase in the "pressor" coefficient, the value of the coefficient ( $\alpha-1)$ became positive, indicating an excessive decrease in the role of peripheral vascular component. At the same time, there was a two-way change in the $Q$ factor in patients with diabetes at different times of the day: its increase at day-time during the first 5 years of diabetes and a gradual decrease of this indicator at night. To date, it is known that low values of the coefficient $Q$ are associated with the risk of developing acute hypotensive states [5]. 
Table 2. The values of the coefficients $\alpha, \alpha-1$ and $Q$ in children with diabetes mellitus, depending on the duration of the disease, $M \pm m$

\begin{tabular}{|c|c|c|c|c|c|}
\hline \multicolumn{2}{|c|}{ Parameter, units } & \multicolumn{4}{|l|}{ Groups } \\
\hline & & \multirow{2}{*}{$\begin{array}{l}\text { The } 1^{\text {st }} \text { group, } \boldsymbol{n}=\mathbf{2 2} \\
0.70 \pm 0.05\end{array}$} & \multirow{2}{*}{$\begin{array}{l}\text { The } 2^{\text {nd }} \text { group, } n=24 \\
0.71 \pm 0.09\end{array}$} & \multirow{2}{*}{$\begin{array}{l}\text { The } 3^{\text {rd }} \text { group, } n=26 \\
0.83 \pm 0.06^{* \Delta}\end{array}$} & \multirow{2}{*}{$\begin{array}{l}\text { Controls, } n=20 \\
0.64 \pm 0.04\end{array}$} \\
\hline 24-hour & $\alpha$, arb. unit & & & & \\
\hline & $a-1$, arb. unit & $-0.30 \pm 0.05$ & $-0.29 \pm 0.09$ & $-0.17 \pm 0.06^{*_{\Delta}}$ & $-0.36 \pm 0.04$ \\
\hline & $\mathrm{Q}, \mathrm{mmHg}$ & $84.94 \pm 3.12$ & $91.52 \pm 4.61^{\Delta}$ & $82.59 \pm 3.37$ & $79.18 \pm 2.98$ \\
\hline \multirow[t]{3}{*}{ Daytime } & $\alpha$, arb. unit & $0.58 \pm 0.06$ & $0.64 \pm 0.08$ & $0.82 \pm 0.06^{*_{\Delta}}$ & $0.57 \pm 0.05$ \\
\hline & $\alpha-1$, arb. unit & $-0.42 \pm 0.06$ & $-0.36 \pm 0.08$ & $-0.18 \pm 0.06^{*_{\Delta}}$ & $-0.43 \pm 0.05$ \\
\hline & $\mathrm{Q}, \mathrm{mmHg}$ & $89.15 \pm 4,32^{\Delta}$ & $91.87 \pm 5.05^{\Delta}$ & $90.30 \pm 3.88^{\Delta}$ & $75.11 \pm 4.14$ \\
\hline \multirow[t]{3}{*}{ Nighttime } & a, arb. unit & $0.73 \pm 0.07^{\Delta}$ & $0.97 \pm 0.09^{\wedge}$ & $1.13 \pm 0.09^{\star_{\Delta}}$ & $0.45 \pm 0.07$ \\
\hline & $a-1$, arb. unit & $-0.27 \pm 0.07^{\Delta}$ & $-0.03 \pm 0.09^{\wedge}$ & $0.13 \pm 0.09^{* \Delta}$ & $-0.55 \pm 0.07$ \\
\hline & $\mathrm{Q}, \mathrm{mmHg}$ & $77.25 \pm 7.94$ & $64.49 \pm 7.58$ & $56.24 \pm 6.12^{\star \Delta}$ & $80.70 \pm 4.74$ \\
\hline
\end{tabular}

$\Delta: P<0.05-$ in the period with the control group; *: $P<0.05-$ in the period with the group of patients with diabetes mellitus up to 1 year.

Table 3. Variants of hemodynamic phenotypes in children with diabetes mellitus, depending on the duration of the disease, $\%$

\begin{tabular}{|c|c|c|c|c|c|}
\hline \multicolumn{2}{|c|}{ Variants of hemodynamic phenotypes } & \multicolumn{4}{|l|}{ Groups } \\
\hline & & \multirow{2}{*}{$\begin{array}{l}\text { The } 1^{\text {st }} \text { group, } n=22 \\
81.8\end{array}$} & \multirow{2}{*}{$\begin{array}{l}\text { The } 2^{\text {nd }} \text { group, } n=24 \\
53.8^{\Delta *}\end{array}$} & \multirow{2}{*}{$\begin{array}{l}\text { The } 3^{\text {rd }} \text { group, } \mathbf{n}=\mathbf{2 6} \\
31.2^{\Delta^{*}}\end{array}$} & \multirow{2}{*}{$\begin{array}{l}\text { Controls, } \mathrm{n}=\mathbf{2 0} \\
80.0\end{array}$} \\
\hline 24-hour & Harmonic & & & & \\
\hline & Myocardial-insufficient subtype of harmonic & 18.2 & 30.8 & 12.5 & 20.0 \\
\hline & Borderline diastolic harmonic & - & 7.7 & - & - \\
\hline & Dysfunctional diastolic & - & 15.4 & 50.1 & - \\
\hline & Dysfunctional systolic & - & - & 6.2 & - \\
\hline \multirow[t]{5}{*}{ Daytime } & Harmonic & 63.6 & 61.5 & $50.0^{4}$ & 80.0 \\
\hline & Myocardial-insufficient subtype of harmonic & $36.4^{4}$ & 30.8 & $12.5^{\Delta *}$ & 20.0 \\
\hline & Borderline diastolic harmonic & - & 7.7 & 6.3 & - \\
\hline & Dysfunctional diastolic & - & - & 25.0 & - \\
\hline & Dysfunctional systolic & - & - & 6.2 & - \\
\hline \multirow[t]{5}{*}{ Nighttime } & Harmonic & 45.4 & 61.5 & $18.7^{\Delta *}$ & 40.0 \\
\hline & Myocardial-insufficient subtype of harmonic & $27.3^{\Delta}$ & $7.7^{\Delta^{\star}}$ & $18.7^{\Delta}$ & 60.0 \\
\hline & Borderline diastolic harmonic & 9.1 & 7.7 & - & - \\
\hline & Dysfunctional diastolic & 18.2 & 15.4 & $56.3^{\Delta}$ & - \\
\hline & Dysfunctional systolic & - & 7.7 & 6.3 & - \\
\hline
\end{tabular}

$\Delta: P<0.05-$ in the period with the control group; *: $P<0.05-$ in the period with the group of patients with diabetes mellitus up to 1 year.

Subsequently, we analyzed the frequency of variants of hemodynamic phenotypes in children with diabetes, taking into account the duration of the disease (Table 3).

It was found that in the control group harmonic or myocardial-insufficient subtype of the harmonic phenotype dominated, which indicated the provision of blood circulation mainly due to the propulsive work of the left ventricle than the peripheral (vascular) component [5].

In the group of patients with diabetes mellitus lasting up to 1 year during the day, all children had harmonious hemodynamic phenotypes. At night, harmonious hemodynamic phenotypes were determined in the vast majority $(72.7 \%)$, borderline diastolic phenotype was observed in $9.1 \%$ of patients, and a dysfunctional-diastolic hemodynamic phenotype was established in other $18.2 \%$ of this group patients. However, the presence of dysfunctional and borderline circulatory phenotypes at night did not affect the overall hemodynamic phenotypes during the day in patients of this group, the analysis of which revealed the absence of pathological variants of hemodynamics.

We observed similar picture of the distribution of variants of hemodynamic phenotypes in the group of diabetic patients with disease duration from 1 to 5 years, among which harmonious hemodynamic phenotypes also dominated during the observation period.
In the long-term course of diabetes mellitus, the proportion of children with a harmonious hemodynamic phenotype during the 24-hour ABPM was statistically lower than among patients in the first 5 years of the disease $(P<0.05)$. It was noteworthy that the largest changes in hemodynamics in patients of this group were observed at night. Thus, if during the day harmonic hemodynamic phenotypes were determined in $62.5 \%$ of patients, then at night we encountered these phenotypes 1.7 times less often $-37.4 \%$ of cases $(P<0.05)$. At the same time, the share of dysfunctional phenotypes at night increased by 2 times due to an increase in the number of patients with dysfunctional-diastolic hemodynamic phenotype $(P<0.05)$. Thus, if in the first 5 years of diabetes mellitus harmonious cardiovascular interaction in circulatory system was observed in patients mostly, then with disease duration over 5 years hemodynamic parameters in most patients corresponded to dysfunctional conditions, among which the diastolic-dysfunctional phenotype dominated.

Given the above, we analyzed the ambulatory arterial vascular stiffness index (AASI) (Table 4). The analysis showed that in the majority $(95.0 \%)$ of children in the control group, the AASI values during the day were less than 0.3 arb. units, i.e. did not exceed the threshold between normal and high blood pressure in children [11].

At the same time, in children with diabetes, there was a significant increase in this index in all observation 
Table 4. AASI in children with diabetes mellitus, depending on the duration of the disease, $M \pm m$

\begin{tabular}{l|l|l|l|l} 
AASI & $\begin{array}{l}\text { Groups } \\
\text { The } 1^{\text {1t }} \text { group, } \mathbf{n = 2 2}\end{array}$ & The $2^{\text {nd }}$ group, $\mathbf{n = 2 4}$ & The $3^{\text {rd }}$ group, $\mathbf{n = 2 6}$ & Controls, $\mathbf{n = 2 0}$ \\
\hline 24-hour & $0.46 \pm 0.04^{\Delta}$ & $0.47 \pm 0.05^{\Delta}$ & $0.54 \pm 0.04^{\Delta}$ & $0.26 \pm 0.03$ \\
Daytime & $0.43 \pm 0.04^{\Delta}$ & $0.46 \pm 0.05^{\Delta}$ & $0.68 \pm 0.05^{\wedge}$ & $0.33 \pm 0.04$ \\
Nighttime & $0.30 \pm 0.04$ & $0.38 \pm 0.04^{\Delta}$ & $0.51 \pm 0.03^{\Delta *}$ & $0.22 \pm 0.05$ \\
\hline
\end{tabular}

$\Delta: P<0.05-$ in the period with the control group; *: $P<0.05-$ in the period with the group of patients with diabetes mellitus up to 1 year.

groups during the 24-hour ABPM with a tendency to increase in the dynamics of the disease $(P>0.05)$. When comparing the values of AASI at different times of the day in patients with diabetes it was found that if during the day there was the AASI increase by 1.5-2.0 times in all groups of patients, then at night the values of this index differed depending on the duration of the disease. Thus, in patients of group 1, the average value of AASI did not exceed 0.3 arb. units, corresponding to a similar index of the control group, while patients with longer course of diabetes AASI averages exceeded the norm.

The most significant increase of AASI was observed in patients with diabetes mellitus lasting more than 5 years compared with both the control group and the $1^{\text {st }}$ group of patients $(P<0.05)$. That is, the results showed a gradual increase in vascular rigidity with increasing duration of diabetes.

Individual analysis of AASI values confirmed our assumption. It was found that in the dynamics of the disease there was a decrease in the proportion of patients in whom the AASI index did not exceed the limit values (Fig. 1). If in the first year of the disease $45.4 \%$ of children had normal AASI during the day, then with the duration of diabetes from 1 to 5 years, the number of children with normal values of this index decreased by 2 times and amounted to $23.1 \%(P<0.05)$. In Group 3 we saw the lowest number of patients with normal vascular stiffness index (12.5\%), which was 3.6 times less than in the first year of the disease $(P<0.05)$.

When analyzing the AASI index in patients with diabetes, depending on the time of day, similar changes were found. Thus, in the first year of diabetes, normal AASI values during the day were registered in $36.4 \%$. Subsequently, there was a decrease in the number of patients in whom this index did not exceed 0.3 arb. units up to $15.4 \%$ in group 2 patients and $6.25 \%$ in group $3(P<0.05)$.

The most significant changes in the AASI index were observed at night. If in the $1^{\text {st }}$ group $72.8 \%$ of patients had normal AASI, then in patients of groups 2 and 3 , respectively, only in $23.1 \%$ and $18.7 \%$ of children there was no increase in this index $(P<0.05)$. It should be noted that during the night period in the first year of the disease in no case was an increase in the AASI index over 0.5 arb. units. Also noteworthy was the fact that, in contrast to group 1, in groups 2 and 3 were found patients with pathological AASI values (more than 0.7 arb. units) both during the day $(38.5 \%$ and $37.5 \%$, respectively) and at night $(7.7 \%$ and $7.1 \%$, respectively), which may indicate severe vascular rigidity and the development of diabetic angiopathy. A direct correlation was established between AASI and PP values $(r=+0.42, P<0.05)$. These data are consistent with the results of other studies in which PP is considered as a sign of increased stiffness of the walls

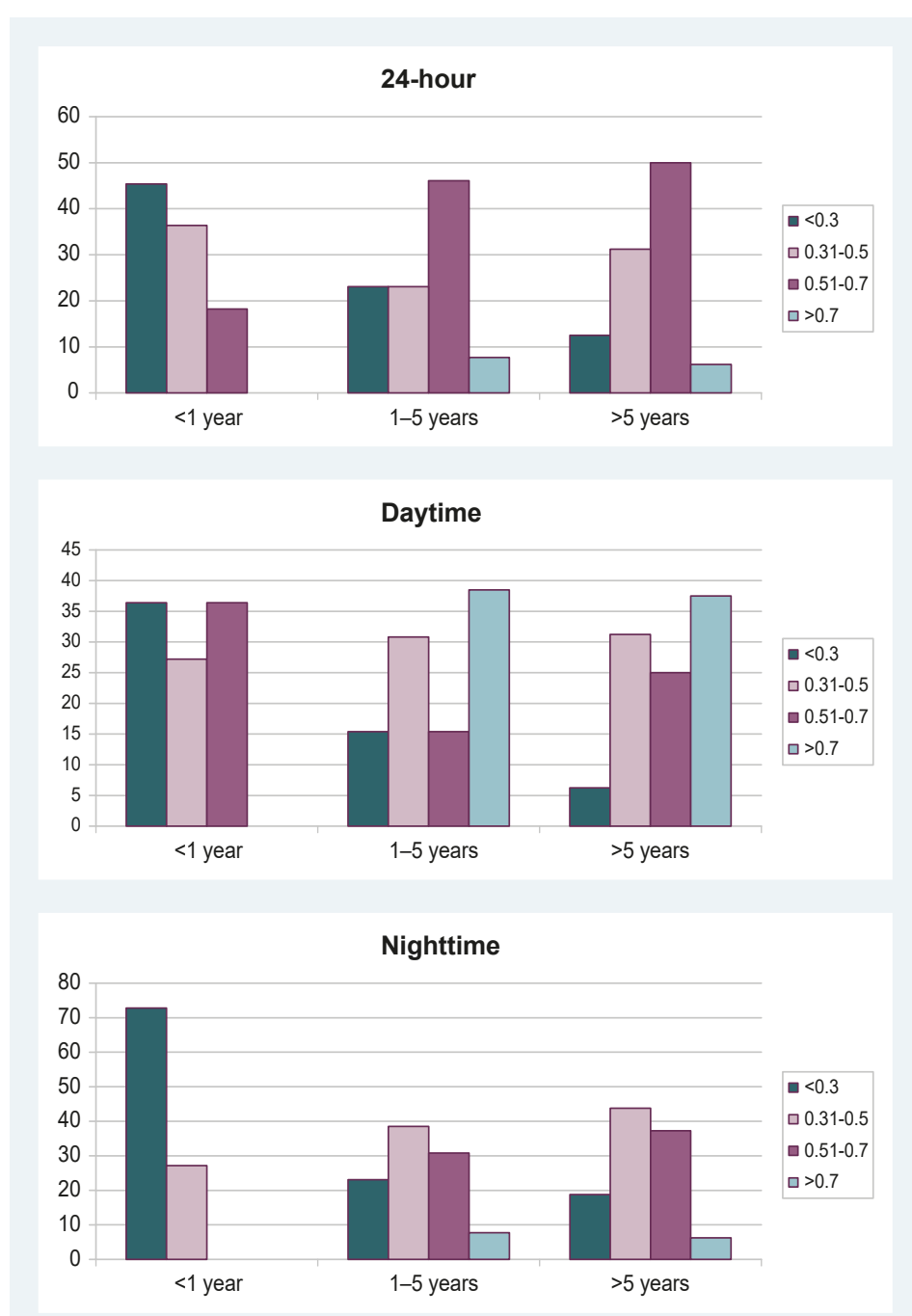

Fig. 1. The value of AASI in patients with diabetes at different times of the day depending on the duration of the disease.

of blood vessels and, in particular, the aorta, and is a risk factor for cardiovascular disorders $[1,8,11]$.

In order to clarify the relationship between hemodynamic features and the state of blood vessels, we further analyzed the parameters of hemodynamic phenotypes depending on the AASI (Table 5). The analysis of the obtained data showed that in patients in whom the AASI exceeded the normative values, there was an increase in the coefficient $\alpha$ and a decrease in the coefficient $Q$, which indicated the development of hemodynamic disorders due to increased vascular stiffness. It was noteworthy that the statistical significance of these changes was acquired at night, which may indicate the development of nocturnal hypertension. 
Table 5. Values of $\alpha$ and $Q$ coefficients in children with diabetes mellitus, depending on the AASI, Me [Q25; Q75]

\begin{tabular}{|c|c|c|c|}
\hline \multirow[t]{2}{*}{ Parameter, units } & & \multicolumn{2}{|l|}{ AASI } \\
\hline & & up to 0.3 arb. unit & over 0.3 arb. unit \\
\hline \multirow[t]{2}{*}{ 24-hour } & $a$, arb. unit & $0.61[0.28 ; 0.70]$ & $0.71[0.58 ; 0.89]$ \\
\hline & $\mathrm{Q}, \mathrm{mm} \mathrm{Hg}$ & $93.6[91.2 ; 94.1]$ & $82.5[72.4 ; 95.1]$ \\
\hline \multirow[t]{2}{*}{ Day-time } & $\alpha$, arb. unit & $0.73[0.33 ; 0.84]$ & $0.78[0.63 ; 0.84]$ \\
\hline & $\mathrm{Q}, \mathrm{mm} \mathrm{Hg}$ & $86.7[86.6 ; 105.3]$ & $83.5[80.0 ; 101.3]$ \\
\hline \multirow[t]{2}{*}{ Night-time } & $\alpha$, arb. unit & 0.64 [0.33: 1.12] & $0.94[0.64 ; 1.34]^{*}$ \\
\hline & $\mathrm{Q}, \mathrm{mm} \mathrm{Hg}$ & $83.9[58.4 ; 110.8]$ & $67.5[44.1 ; 82.2]^{*}$ \\
\hline
\end{tabular}

*: $\mathrm{P}<0.05-$ in comparison with similar parameters at AASI to 0.3 arb. units.

\section{Discussion}

The study revealed the features of hemodynamic phenotyping by blood pressure parameters in children with diabetes. It was found that in children with diabetes mellitus, in the dynamics of disease there was a deviation from the normative parameters of hemodynamic phenotypes: an increase during the day the level of "pressor" coefficient $\alpha$, "depressant" coefficient $(\alpha-1)$ and bidirectional changes in $Q$ (increase during the day and its decrease at night). The established changes indicate excessive involvement of the myocardium in the movement of blood due to increased cardiac output against the background of a significant weakening of the role of the "peripheral, vascular" component of the circulatory process [4].

At the same time, it is known that the coefficient $Q$ reflects the blood pressure in the terminal part of the arterioles, where blood flow becomes constant (nonpulsating) and characterizes the level of metabolism between blood and organs [4]. In view of the above, it can be assumed that a moderate increase in $Q$ is a positive adaptive phenomenon aimed at improving blood supply, in particular, to skeletal muscles, which is known to play an important role in glucose metabolism. Accordingly, a decrease in the coefficient $Q$ at night by 1.5 times in patients of group 3 compared with the control group $(P<0.05)$, may be a risk factor for acute hypotensive conditions at night [5].

Further analysis of hemodynamic phenotypes revealed that children with long-term diabetes develop hemodynamic disorders, among the phenotypes of which diastolic-dysfunctional is dominating. It is believed that in this hemodynamic phenotype there are latent hemodynamic disorders, which are associated with increased vascular stiffness $[3,5]$.

Confirmation of this assumption was a gradual increase in the outpatient arterial vascular stiffness index in the dynamics of diabetes. The diastolicdysfunctional phenotype of hemodynamics, along with high values of AASI, in the conditions of their long-term preservation, act as a risk factor for the development of hypertension in the future $[5,6]$. The formation of systolic dysfunctional hemodynamic phenotype in some children with diabetes mellitus may be a sign of increased total peripheral vascular resistance and is associated with the development of vascular spasms [5]. Therefore, patients with dysfunctional hemodynamic phenotypes, even in the presence of normotension, are at increased risk of developing hypertension and require dynamic monitoring.

\section{Conclusions}

1. In children with diabetes mellitus the dynamics of the disease demonstrates the formation of disharmonious hemodynamic phenotypes against the background of increased vascular stiffness, which in combination with increase in rigidity of vessels is realized by disturbance of systemic blood circulation and development and progression of diabetic angiopathy and, obviously, acts as risk factors of development of arterial hypertension.

2. Determination of hemodynamic phenotype in children with diabetes mellitus can be used as screening method for preclinical diagnosis of latent disorders of the cardiovascular system, early treatment and prevention.

Prospects for further research. In the future, it is planned to conduct a population study of hemodynamic phenotypes in children with diabetes mellitus.

Conflicts of interest: authors have no conflict of interest to declare. Конфлікт інтересів: віАсутній.

Надійшла Ао реАакції / Received: 01.12.2020

Після Аоопрацювання / Revised: 27.01.2021

Прийнято Ао Аруку / Accepted: 03.02.2021

\section{Information about authors:}

Lezhenko H. O., MD, PhD, DSc, Head of the Department of Hospital Pediatrics, Zaporizhzhia State Medical University, Ukraine.

ORCID ID: 0000-0003-0851-4586

Pashkova 0. Ye., MD, PhD, DSc, Professor of the Department of Hospital Pediatrics, Zaporizhzhia State Medical University, Ukraine.

ORCID ID: 0000-0002-3935-5103

Samoilyk K. V., MD, PhD, Assistant of the Department of Hospital Pediatrics, Zaporizhzhia State Medical University, Ukraine.

Відомості про авторів:

Леженко Г. О., А-р меА. наук, професор, зав. каф. госпітальної педіатрії, Запорізький Аержавний медичний університет, україна.

Пашкова О. Є., А-р меА. наук, професор каф. госпітальної педіатрії, Запорізький Аержавний медичний університет, Україна.

Самойлик К. В., канА. меА. наук, асистентка каф. госпітальної педіатрії, Запорізький Аержавний медичний університет, україна.

\section{Сведения об авторах:}

Леженко Г. А., А-р меА. наук, профессор, зав. каф. госпитальной педиатрии, Запорожский государственный меАицинский университет, Украина.

Пашкова Е. Е., А-р меА. наук, профессор каф. госпитальной педиатрии, Запорожский государственный медицинский университет, Украина. 
Самойлик Е. В., канА. меА. наук, ассистент каф. госпитальной педиатрии, Запорожский государственный меАицинский университет, Украина.

\section{References}

[1] Delyagin, V. M., Urazbagambetov, A., Korolev, A. V., Kilikovsky, V. V., \& Olimpieva, S. P. (2014). Indeks zhestkosti arterial'noi stenki v traktovke rezul'tatov sutochnogo monitorirovaniya arterial'nogo davleniya [Arterial wall stiffness index in interpretation of the results of ambulatory blood pressure monitoring]. Detskaya bol'nitsa, (1), 17-22. [in Russian].

[2] Zelinska, N. B., Rudenko, N. G., Globa, E. V., Shevchenko, I. Yu., \& Kavetska, Yu. S. (2019). Dytiacha endokrynolohiia v Ukraini u 2018 rotsi [Pediatric endocrinology in Ukraine in 2018]. Ukrainskyi zhurnal dytiachoi endokrynolohii, (1), 7-15. [in Ukrainian]. https://doi. org/10.30978/UJPE2019-1-7

[3] Khursa, R. V. (2015). Latentnye narusheniya krovoobrashcheniya u molodykh lyudei i ikh korrektsiya pri modifikatsii obraza zhizni s vklyucheniem fizicheskikh nagruzok [Latent circulatory disorders in young people and their correction during lifestyle modification with the inclusion of physical activity]. In K. Yu. Romanov, E. S. Vand (Eds.), Ozdorovitel'naya fizicheskaya kul'tura molodezhi: aktual'nye problemy i perspektivy. Proceedings of the 2nd International Scientific and Practical Conference (pp. 131-136). Minsk: BSMU. [in Russian].

[4] Khursa, R. V., \& Zabela, Ye. I. (2019). Gemodinamicheskie fenotipy u prakticheski zdorovykh molodykh lyudei s raznym urovnem fizicheskoi podgotovki [Hemodynamic phenotypes in healthy young people with differernt levels of physical training]. Voennaya meditsina, (3), 112117. [in Russian].

[5] Khursa, R. V., Mesnikova, I. L., Eremina, N. M., \& Voitikova, M. V. (2018). Metod opredeleniya gemodinamicheskogo fenotipa [Method for determining the hemodynamic phenotype]. Minsk: BSMU. [in Russian]

[6] Tseluiko, V. I., Bregvadze, T. R., \& Mishchuk, N. Ye. (2012). Faktory, assotsiirovannye s pokazatelyami tsentral'nogo aortal'nogo davleniya u bol'nykh s arterial'noi gipertenziei [Factors associated with central aortic pressure parameters in patients with arterial hypertension]. Ukrainskyi kardiolohichnyi zhurnal, (10), 58-66. [in Russian].

[7] Khunti, K., Davies, M., Majeed, A., Thorsted, B. L., Wolden, M. L., \& Paul, S. K. (2015). Hypoglycemia and risk of cardiovascular disease and all-cause mortality in insulin-treated people with type 1 and type 2 diabetes: a cohort study. Diabetes care, 38(2), 316-322. https://doi. org/10.2337/dc14-0920

[8] Muxfeldt, E. S., Cardoso, C. R., Dias, V. B., Nascimento, A. C., \& Salles, G. F. (2010). Prognostic impact of the ambulatory arterial stiffness index in resistant hypertension. Journal of hypertension, 28(7), 1547-1553. https://doi.org/10.1097/HJH.0b013e328339f9e5

[9] Diabetes Control and Complications Trial/Epidemiology of Diabetes Interventions and Complications (DCCT/EDIC) Research Group (2016). Risk Factors for Cardiovascular Disease in Type 1 Diabetes. Diabetes, 65(5), 1370-1379. https://doi.org/10.2337/db15-1517

[10] Schofield, J., Ho, J., Soran, H. (2019). Cardiovascular Risk in Type 1 Diabetes Mellitus. Diabetes therapy : research, treatment and education of diabetes and related disorders. 10(3), 773-789. https://doi. org/10.6084/m9.figshare.7901828

[11] Simonetti, G. D. Von Vigier, R. O Wühl, E \& Mohaupt, M. G. (2008). Ambulatory arterial stiffness index is increased in hypertensive childhood disease. Pediatric research, 64(3), 303-307. https://doi. org/10.1203/PDR.0b013e31817d9bc5 